\title{
Twenty Years after the Killing of the King of Kingpins Pablo Escobar: Lessons Learned from Narco-Terrorism
}

\author{
Michael W. Parra ${ }^{1 *}$ and José Mauricio Suárez-Becerra² \\ ${ }^{1}$ International Trauma Critical Care Improvement Project/ Broward General Level I Trauma Center/ Delray Provisional Level I Trauma Center, FL, USA \\ ${ }^{2}$ Asociación Colombiana de Trauma, Secretario Ejecutivo, Pereira, Colombia
}

Pablo Escobar (1949 -1993) once said that "All empires are created of blood and fire" [1]. In 1987 Forbes magazine estimated Escobar to be the seventh-richest man in the world with a personal wealth of close to US $\$ 25$ billion, while his Medellin cartel controlled $80 \%$ of the global cocaine market $[2,3]$.

The term narco-terrorism has been exemplified by Pablo Escobar as the classic drug trafficker who used terrorist tactics against noncombatants to further his political agenda and to protect his drug trade [4]. Escobar's ruthlessness was legendary. He had a way of dealing with his enemies: he called it "plata o plomo" literally, silver or lead. Usually, if a politician, judge or police officer got in his way, he would first attempt to bribe them, and if that didn't work, he would order them killed, occasionally including their family [5]. The exact number of persons killed by Escobar is unknown, but it definitely goes well into the hundreds and perhaps into the thousands.

The Medellin cartels continuing struggle to maintain supremacy resulted in Colombia's quickly becoming the world's murder capital with 25,100 violent deaths in 1991 and 27,100 in 1992 [6]. Living in the country during this time was associated with a 16 times greater likelihood of becoming a victim of terrorist violence as compared to any other South American country citizen [7]. According to the Pan American Health Organization (PAHO) the Colombian murder rate was 64 per 100,000 inhabitants compared to the 5.6 per 100,000 rate seen in the U.S. or the even lower figure of 0.6 per 100,000 seen in England [8].

Escobar was responsible for the 1985 storming of the Colombian Supreme Court, the 1989 murder of Colombian presidential candidate Luis Carlos Galan, the bombing of Avianca Flight 203 and the DAS building bombing in Bogotá. The 1985 storming of the Colombian Supreme Court by left-wing guerrillas from the 19th of April Movement, also known as M-19, resulted in the murder of more than 70 people, including eleven Supreme Court justices. At the time of the siege, the Supreme Court was studying the constitutionality of Colombia's extradition treaty with the U.S. The M-19 were paid to break into the building of the supreme court, and burn all papers and files on" Los Extraditables" - the group of cocaine smugglers, which included Pablo Escobar, who were under threat of being extradited to the US by the Colombian government. Avianca Airlines Flight 203 was a Colombian domestic passenger flight that was destroyed by a bomb on November 27, 1989. All 107 passengers on board were killed. The purpose of the attack was to assassinate the presidential candidate for the 1990 elections César Gaviria Trujillo. Gaviria, however, was not on the plane, and would go on to become President of Colombia. The DAS building bombing was a truck bomb attack in Bogotá, Colombia, at 7:30 am on December 6, 1989. The bomb targeted the Administrative Department of Security (DAS) headquarters, which is the equivalent to our CIA Headquarters in Langley, Virginia. The truck bomb, with an estimated $500 \mathrm{~kg}$ of dynamite, leveled several city blocks, killed 52 people and injured more than 1,000. The bombing was an attempt to assassinate DAS director Miguel Maza Márquez, who escaped unharmed [5].
In 1992 United States Operators from Delta Force and Central Spike joined the all-out manhunt for Escobar. They trained and advised a special Colombian police task force, known as the "Search Bloc". The war against Escobar ended on December 2, 1993. He was found hiding in a middle-class barrio in Medellín and was shot and killed by Colombian National Police while attempting to escape capture by running across the roof tops [9] [Figure 1].

After Escobar's death and the fragmentation of the Medellín Cartel the cocaine market soon became dominated by the rival Cali Cartel, until the mid-1990s when its leaders, too, were either killed or captured by the Colombian government. The death of the mayor kingpins of the Colombian drug trade has given way to many small technologically and socially sophisticated, and less integrated drug cartels.

Narco-terrorism has placed an enormous burden on Colombia and its people but in return it has also catalyzed important systematic changes. These include the development and advancement in emergency medical services and human capacity initiatives such as the development of a dedicated Colombian Medical Trauma Society (ACT) and also a Trauma Surgical Critical Care Fellowship in the city

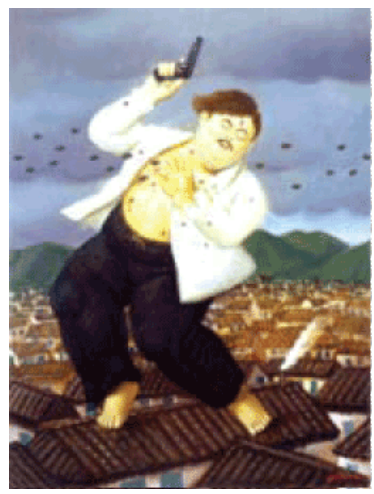

Figure 1: Pablo Escobar's death portrayed by fellow Colombian artist Fernando Botero.

*Corresponding author: Michael W. Parra, Trauma Research Director, Associate Clinical Professor, Division of Trauma/Surgical Critical Care, International Trauma Critical Care Improvement Project, Broward General Level I Trauma Center, Delray Provisional Level I Trauma Center, NOVA Southeastern School of Medicin, $1600 \mathrm{~S}$. Andrews Ave, Fort Lauderdale, FL 33316, USA, Tel: 786-547-9685; Fax: 954-4685238; E-mail: michaelwparra@yahoo.com

Received December 02, 2011; Accepted February 10, 2012; Published February 20,2012

Citation: Parra MW, Suárez-Becerra JM (2012) Twenty Years after the Killing of the King of Kingpins Pablo Escobar: Lessons Learned from Narco-Terrorism. J

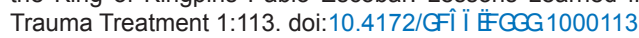

Copyright: @ 2012 Parra MW, et al. This is an open-access article distributed unde the terms of the Creative Commons Attribution License, which permits unrestricted use, distribution, and reproduction in any medium, provided the original author and source are credited. 
Citation: Parra MW, Suárez-Becerra JM (2012) Twenty Years after the Killing of the King of Kingpins Pablo Escobar: Lessons Learned from NarcoTerrorism. J Trauma Treatment 1:113. doi:10.4172/ń⿴ ńń⿴囗n ńńn.1000113

Page 2 of 2

of Cali, which is the first in its class in Latin America. The Colombian government has also enacted new legislation to define standards and to assure widespread quality of pre-hospital and hospital care nationwide. Benefits of this new legislation have included, among other things, establishment of increased numbers of pre-hospital training institutions, the creation of the General Direction for the Prevention and Emergency Response to Disasters (DGPAD) and a Unified Emergency Management System (SUME) [10].

The DGPAD is the national agency responsible for the overall command and coordination of the national response to emergencies and disasters. The DGPAD operates within the Ministry of the Interior and is under the direction of the president. At the local level a terrorism response plan SUME has been implemented in the countries capital Bogota that includes the healthcare system response at the pre-hospital and hospital levels. At the pre-hospital level, the plan includes search and rescue activities, triage and stabilization at the site of the event, transportation and even decontamination and HazMat maneuvers. Both the pre-hospital and hospital levels of emergency response are coordinated by the city's Emergency Regulation Center (CRU), which also has communication with public safety and security agencies. If necessary, the CRU also is able to coordinate emergency response at the national level [10].

The implementation of these public policies related to prevention and public security have already produced major beneficial results. For example, the number of deaths by homicide has dropped dramatically after reaching epidemic proportions in the mid - 1990s, from 80 per 100,000 inhabitants in 1993 to 30 per 100,000 inhabitants in 2001 [10].

With 1.6 million people killed in violent incidents throughout the world every year, the lessons learned from the Colombian experience with narco-terrorism are of extreme importance for the rest of the world. ${ }^{[6]}$ Today, however, governments such as the Colombian find themselves still faced with terrorists who out of convenience or necessity, use drug money to further their cause. So the plague of narco-terrorism still persists even after the death of Pablo Escobar. That is why narco-terrorism is a worldwide epidemic that demands our attention to improve our overall emergency preparedness and disaster management for potential future events.

\section{References}

1. Paez-Parada J (2010) A talk with Colombian journalist Elizabeth Mora-Mass.

2. http://en.wikipedia.org/wiki/Pablo_Escobar\#cite_ref-BBCMarch2009_15-0

3. (2011) Pablo Emilio Escobar 1949 - 19939 Billion USD - The business of crime - 5 success stories.

4. http://www.au.af.mil/au/awc/awcgate/congress/narco_terror_20may03.pdf

5. Escobar R (2009) The Accountant's Story: Inside the violent world of the Medellin Cartel. Grand Central Pub.

6. (2010) Inter-American Commission on Human Rights - Chapter II: The Violence Phenomenon. Organization of American States.

7. Baez AA, Sztajnkrycer MD, Zane R, Giraldez E (2008) Twenty-five years of violence: The epidemiology of terrorism in South America. Prehosp Disaster Med 23:128-132

8. Ceaser M (2007) Colombia continues to struggle with violence. Lancet 370 1601-1602.

9. Bowden M (2002) Killing Pablo: The hunt for the World's greatest outlaw Penguin Pub.

10. Paredes Zapata GD (2003) Terrorism in Colombia. Prehosp Disaster Med 18 80-87. 